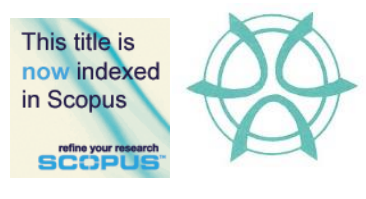

PLANNING MALAYSIA:

Journal of the Malaysian Institute of Planners

VOLUME 17 ISSUE 1 (2019), Page 350 - 364

\title{
HOW ICT IMPLEMENTATIONS IMPACT ON MANAGING REAL ESTATE: AT DIRECTORATE GENERAL STATE ASSET MANAGEMENT, MINISTRY OF FINANCE, INDONESIA
}

\author{
Aris Suhada Mian ${ }^{1}$ \\ ${ }^{1}$ MINISTRY OF FINANCE, INDONESIA
}

\begin{abstract}
The research background identifies the opportunities as well as challenges of ICT Implementation by reviewing the existing condition compared to IT-governance best practice. This paper aims to reveal strategies from IT governance framework for overcoming the implementation real-estate information system issues. Then, this paper provides recommendations that may help the lawmakers to adopt ITgovernance principles for ICT implementation in DGSAM. Data sources are from literature review of journals and articles from the electronic library to reveal the best practice on IT-governance while engaging with current situation as a baseline derived from observation. The inhibitor factors found are not solely examined from the technical perspective. In this journal, it is clarified that organisations demand IT-governance for totally transforming from conventional to modern real estate e-business. This paper enables DGSAM to be more likely to have an overview on how ICT is implemented successfully by revealing the gaps between IT-governance concept and the existing condition.
\end{abstract}

Keywords: IT-governance, E-government, online self-service, asset management, valuation, auction 
PLANNING MALAYSIA

Journal of the Malaysia Institute of Planners (2019)

\section{INTRODUCTION}

The Directorate General of State Asset Management (DGSAM) is a government institution organised and administered under The Ministry of Finance in Indonesia who is responsible for concerning state assets, valuation, auction, and state receivables. Several actions have been taken in order to achieve its vision. Firstly, it is necessary to realise the state revenue optimisation, expenditure efficiency and state asset effectiveness. The next thing to consider is to protect state assets physically and to collect all legal documents. Thirdly, it is important to improve the government investment. Later, DGSAM has to realise accrual or fair value of state assets which can be used for various needs i.e. underlying assets. Then, it is vital to implement the effectiveness of and the efficiency in asset valuation. Last but not least, DGSAM needs to realise proper auction as a method of buying and selling industry for public domain.

The DGSAM's stakeholders are various, including but are not limited to government institutions, corporations, banks, public and personal. Several services delivered to those stakeholders consist of 13 (thirteen) types from various levels or service workplaces: headquarter, regional offices and branch offices. Referring to customer satisfaction document 2015 those 13 services contains state asset, valuation and auction at three level service workplaces as mentioned before.

The research objectives are as follows: first, to understand the current level of information systems implementation from three core business processes as a baseline of future implementation online self-service; next, to identify and consider the risk of online self-service scheme that possibly emerges without an understanding of IT governance principle, leading to the identification of contribution to current stagnant e-government implementation; third, to understand the extents of conceptual IT-governance framework and strategy implementation within three core systems at DGSAM.

\section{LITERATURE REVIEW}

\section{IT Governance}

The definition of IT-Governance varies from scholar to scholar. According to De Haes and Van Grembergen (2015), Enterprise Governance of IT is defined as "an integral part of corporate governance and addresses the definition and implementation of processes, structures and relational mechanisms in the organisations that enable both business and IT people to execute their responsibilities in supporting of business/IT alignment and the creation of business value from IT-enabled business investments". Why IT governance in an organisation is crucial? Information Technology becomes an opportunity to differentiate and to achieve competitive advantages (De Haes \& Van Grembergen, 2009). Those two experts have been conducting previous research 
Aris Suhada Mian

How ICT Implementations Impact on Managing Real Estate: At DGSAM, Ministry of Finance, Indonesia

using exploratory study method into IT governance implementations and its impact on business/IT alignment for six case organisations. Some mature organisations are commonly adopting IT to support business, and let IT lead business process transformation, such as at banking or financial system (Blanton, Watson, \& Moody, 1992; Van Grembergen \& Saull, 2001).

Researchers describe that without IT-Governance the risk factor has become costly for any organisations whose businesses rely heavily on IT (De Haes \& Van Grembergen, 2009). Take for example how costly the negative impact of downtime on electronic auction payment system. Moreover, financial and managerial levels are questioning how much IT capital investments compared to the benefits for organisation or return on investment (ROI). A technique such as IT balance-scorecard is proposed to measure the effectiveness of IT investment not only viewed from financial perspective, but also taken from customer, internal process, and learning and growth perspective (Kaplan \& Norton, 2005; Melville, Kraemer, \& Gurbaxani, 2004). Therefore, any organisations who invest on IT, particularly IT- governance, benefit the entities as well as reduce the risk in their business.

To identify the role and the responsibility of IT governance implementation, an organisation needs to map the layers. In general, an enterprise is divided into three layers: strategic level, management level and operational level (De Haes \& Van Grembergen, 2015). Strategic level is the place where the Board of Directors are involved; management level is where CEO, CIO and senior management take charge, while operational level is when business and IT units need to monitor the process framework. An institution requires a holistic set of framework components of governance processes, structures and relational mechanisms. Indeed, the IT alignment becomes the most significant result of the relationship between IT and business management.

Each component of IT-governance will capture and produce strategic methods for organisation. Initially, the structure component has a responsibility to formulate IT decisions and to establish a mutual relationship between business and IT management in terms of decision-making process. Secondly, the process itself means the establishment of strategic IT decision-making and IT monitoring formulation. The purpose of component process is to ensure the consistency of daily behaviours with the existing policies and to provide improvement feedback to decisions such as service-level agreements (De Haes \& Van Grembergen, 2015). Lastly, relational mechanisms refer to active participation and collaboration among the executives, IT and business management in the form of job-rotation, cross training, and IT-leadership. Those tree framework components will be discussed in detail. 
PLANNING MALAYSIA

Journal of the Malaysia Institute of Planners (2019)

\section{E-Government Index}

E-government utilises Information and Communication Technology (ICT) to attain transformation and reformation by raising transparency, removing the geographical barrier, and encouraging more participation. Although Egovernment is not a novel concept anymore but it has always been a trend in decades for any countries all over the world to set it as a desirable goal to pursue. The United Nations E-Government recorded Indonesia in the position of 116 EGDI (E-Government Development Index) according to survey in 2016 which shows a decrease of 10 level lower than the one in 2014 with 106 EGDI. In that position Indonesia only achieved 0.4478 , which is considered to be far left behind by other Southeast Asian countries; for example Malaysia (60 EGDI), Philippines (71 EGDI), and Brunei Darussalam (83 EGDI) (UNPAN, 2016). The world top rank of EGDI level is the United Kingdom of Great Britain and Northern Ireland in three consecutive years followed by Australia in the second.

E-government in Indonesia has revealed inequality of distribution due to digital division between areas and citizen. Other factors such as policies, institutions, infrastructure, applications, and planning also contribute to a different realisation levels. Developing countries like Indonesia which runs government service in a good governance for the effectiveness and the efficiency in national scale needs to measure detailed level indicators to determine and evaluate the success of e-government implementation rather than to rely on general ones (Palijama, Sumpeno, \& Wibawa, 2016).

\section{Online Self-Service}

Online Self-Service is part of e-government implementation focusing on delivering public services using ICT by allowing customers directly interact digitally through internet without meeting them in person. Online self-service could be operated via government website, mobile application, or client server application accessible by citizens using internet connection.

The availability of online self-service apparatus alone will not guarantee to successful implementation without e-government policies and strategies applied in general and by upgrading specific sectors for the delivery of services. Similar to e-government, online self-service also has a measurement index which the result is close to each other. Indonesia is a part of the middle group of countries, determined by the level of Online Service Index (OSI) which is between 0.25 and 0.50 (UNPAN, 2016). It means Indonesia requires some improvements to boost the index.

Researchers argue that implementing online self-services in government organisations could bring opportunities (Table 1). There are three opportunities which are illustrated in table 1. Learning perspective to be more focus on seeking information needed by customers comes first. Customers tend to find out information initially through a website. The next thing on the list is public 
Aris Suhada Mian

How ICT Implementations Impact on Managing Real Estate: At DGSAM, Ministry of Finance, Indonesia

participation, which means to engage more people to be involved in egovernment website through online self-service as a new way to channel a request. Thirdly, customer satisfaction effects on the online self-service usage.

Table 1: Opportunities of Online Self-Services

\begin{tabular}{lll}
\hline Opportunities & Authors & Explanation \\
\hline $\begin{array}{l}\text { learning } \\
\text { perspective }\end{array}$ & $\begin{array}{l}\text { Jen-Hung \& } \\
\text { Stacy Huey- } \\
\text { Pyng, 2008 }\end{array}$ & $\begin{array}{l}\text { E-government website that contains knowledge } \\
\text { content, navigational aids, and interactive knowledge } \\
\text { sharing are important }\end{array}$ \\
\hline $\begin{array}{l}\text { Public } \\
\text { participation }\end{array}$ & $\begin{array}{l}\text { Pinho, de } \\
\text { "...a number of key aspects of online service quality } \\
\text { Martins, \& } \\
\text { that contributes to the increase of the use of the } \\
\text { taxation web site... This is particularly evident for web } \\
\text { site characteristics such as convenience, research } \\
\text { facilities, privacy and security, speed and ease of } \\
\text { access". }\end{array}$ \\
\hline Customer & Liao, Chen, \\
Satisfaction & $\&$ Yen, 2007 & $\begin{array}{l}\text { Customer satisfaction affected by perceived } \\
\text { usefulness and subjective norm determine customer to } \\
\text { use e-service continually. }\end{array}$ \\
\hline
\end{tabular}

However, the institution should be prepared to welcome any challenges when online self-services are implemented. Each institution has its own characteristics, therefore, generalization is not allowed. Cost is like a double edge sword. In the short period of time, it might be seen as liability. However, in the long run, in terms of working hour and operational cost, it can be classified as efficiency gain. Lack of organisational e-government concept would only be posed as the challenge to the successful implementation of e-government initiatives (Nkohkwo \& Islam, 2013).

Table 2: Challenges of Online Self-Services

\begin{tabular}{lll}
\hline Challenges & Authors & Explanation \\
\hline $\begin{array}{l}\text { Funding / } \\
\text { High Cost }\end{array}$ & $\begin{array}{l}\text { Angelopoulos, } \\
\text { Kitsios, Kofakis, \& } \\
\text { Papadopoulos } \\
(2014) .\end{array}$ & $\begin{array}{l}\text { Government needs to allocate budget to provide } \\
\text { infrastructures such as hardware, software and } \\
\text { people. }\end{array}$ \\
\hline $\begin{array}{l}\text { Security and } \\
\text { Privacy }\end{array}$ & $\begin{array}{l}\text { Gefen, Warkentin, } \\
\text { Pavlou, \& Rose, } \\
(2002)\end{array}$ & $\begin{array}{l}\text { E-government exposes online service users to } \\
\text { unique threats to data privacy and the security of } \\
\text { information. }\end{array}$ \\
\hline Integration & Simon (2013) & $\begin{array}{l}\text { The integration of many IT applications and } \\
\text { data either inside or outside the organisational }\end{array}$ \\
\hline
\end{tabular}


PLANNING MALAYSIA

Journal of the Malaysia Institute of Planners (2019)

\begin{tabular}{|c|c|c|}
\hline & & boundary. \\
\hline $\begin{array}{l}\text { Technical } \\
\text { Infrastructure } \\
\text { / Digital } \\
\text { Divide }\end{array}$ & $\begin{array}{l}\text { Ebrahim \& Irani } \\
(2005) ; \text { Nkohkwo \& } \\
\text { Islam (2013) }\end{array}$ & $\begin{array}{l}\text { Infrastructural aspects, the most important } \\
\text { themes such as ICT infrastructure, internet } \\
\text { access and connectivity and power supply } \\
\text { (Nkohkwo \& Islam, 2013). }\end{array}$ \\
\hline $\begin{array}{l}\text { Shortage IT } \\
\text { Skill }\end{array}$ & $\begin{array}{l}\text { Chen \& Gant } \\
\text { (2002); Ebrahim \& } \\
\text { Irani (2005) }\end{array}$ & $\begin{array}{l}\text { Lack of systems integrator and project } \\
\text { management skills which are able to translate } \\
\text { business to IT (Ebrahim \& Irani, 2005). }\end{array}$ \\
\hline $\begin{array}{l}\text { Organisationa } \\
\text { 1 Barrier }\end{array}$ & $\begin{array}{l}\text { Angelopoulos, } \\
\text { Kitsios, Kofakis, \& } \\
\text { Papadopoulos } \\
\text { (2014); Ebrahim \& } \\
\text { Irani (2005); } \\
\text { Nkohkwo \& Islam } \\
\text { (2013) }\end{array}$ & $\begin{array}{l}\text { refer to structural issues such as division, poor } \\
\text { relational mechanisms and communication } \\
\text { between IT and business unit, and an } \\
\text { acceptance of the strategic benefits of new } \\
\text { initiatives by the senior management } \\
\text { (Angelopoulos et al., 2014). }\end{array}$ \\
\hline
\end{tabular}

\section{Real Estate Application Systems at DGSAM}

This paper focuses on enabling factor from the implementation of application systems in three core business processes: state asset management system, valuation information system, and electronic auction. The reason of choosing those three core applications is because all of those applications represent the whole cycle of managing assets from acquisition to disposal.

The state asset management system is a representation of core business of DGSAM for managing state assets. The benefits are reduced processing time, significant cost-cutting, improved accuracy and the user-monitored quality of data. This application system succeeded in reducing time processing because it had been changing reconciliation behaviour in the previous years (from 2010 to 2014) from visiting the branch office to online reconciliation (start from 2015 until now) via internet. In addition, cost-cutting means every user of State Asset Management System can utilise features to lodge all application requirements online without visiting the office every semester. In point of fact, now the accuracy and quality allow the users to be able to analyse their data first before printing out letters or documents. Surely, with data integration, the important part of information can be acquired in order to manage data integrity in the accrual accounting.

Valuation Information System is designed for managing and controlling record of assets (real-estate and property including lands and buildings). The activity of recording data of asset is part of appraisal job-desk at the Directorate of Valuation. However, those database are strictly prohibited for public (designed for internal use only). Instead, branch office has to provide manual or paper-based if asset-assessment-reports are requested by stakeholders. In the context of 
Aris Suhada Mian

How ICT Implementations Impact on Managing Real Estate: At DGSAM, Ministry of Finance, Indonesia

digitalisation concept, keeping information secure is a serious concern for some reasons, especially for sensitive or confidential information such as property profile. However, the stakeholders are the actual data owners. Therefore should they deserve the transparency?

What are the benefits once public service system goes online-based? We may expect the advantages such as sharing property market value, increase willingness to do transaction due to trust effect (Sonnenschein, Loske, \& Buxmann, 2016). But, DGSAM are still reluctant to give online access. In some countries, like Australia, those data being monetised, to generate government income, as data market comparative.

The latter is the big issue in this system because DGSAM does not have any policy responsible for protecting an organisation's information assets. Management of information security must take into account to design and implement secure systems that will address possible threats in the future (Whitman \& Mattord, 2014). It is necessary to define information security policy and explains its principal function in a successful information security program.

E-Auction is an innovation tool to convert selling method from conventional bidding to electronic one. The electronic auction has been implemented commonly in private sector such as e-bay. Nevertheless, the implementation of electronic auction becomes support strategy as well as potentially shapes new strategy (Van Grembergen \& De Haes, 2009).

One advantage of applying electronic auction online-based is to increase probability to get the highest selling price. Another benefit is to eliminate geographical boundaries. Last but not least, online auction increases the competition in the competitive market. Yet, the challenges are there during the implementation. Likewise, information security has also become the main concern because it is related to the financial transaction.

Business process re-engineering is needed to simplify the complex and long procedural steps when users are willing to participate on e-auction. The readiness of the user to switch from conventional to electronic auction is still far behind the expectation with the proportion is only around 30\% compared to conventional. Therefore, DGSAM must encourage sellers to switch from conventional to an e-auction, even though they face challenges. In addition, eauction campaign to the public and business process simplification is needed to be totally transformed.

\section{METHODOLOGY}

Two methods are used to conduct this paper; first, a literature review of open access journals and articles from the electronic library; second, an observation from capturing the current condition as a benchmark. The gaps are expected to emerge when comparing elements of IT-governance to journal's findings and identifying the missing components at this current situation at DGSAM. There 
PLANNING MALAYSIA

Journal of the Malaysia Institute of Planners (2019)

should be lot of factors required to reach such an optimised maturity level (De Haes \& Van Grembergen, 2009).

\section{Searching Strategy}

Steps to gather academic resources are as follows. First, define the keywords consists of "E-government online self-service" and "IT-Governance". Various academic journal sources are listed from reputable electronic libraries. Three repositories include IEEE, Scopus, and Web of Science. Then apply each keyword with some search filters. Search limited to journal articles and conference papers published between 2006 and 2016. Moreover, to get the high quality results, also apply the sorting based on the number of most citied sources. In addition, the reviewed academic publications are limited to journal articles and conference paper which have been published since 2006. Therefore, some older issues may not be identified and listed in the literature review. Instead of using only electronic databases that have been mentioned above, this paper also optimises Google scholar to find more information broadly.

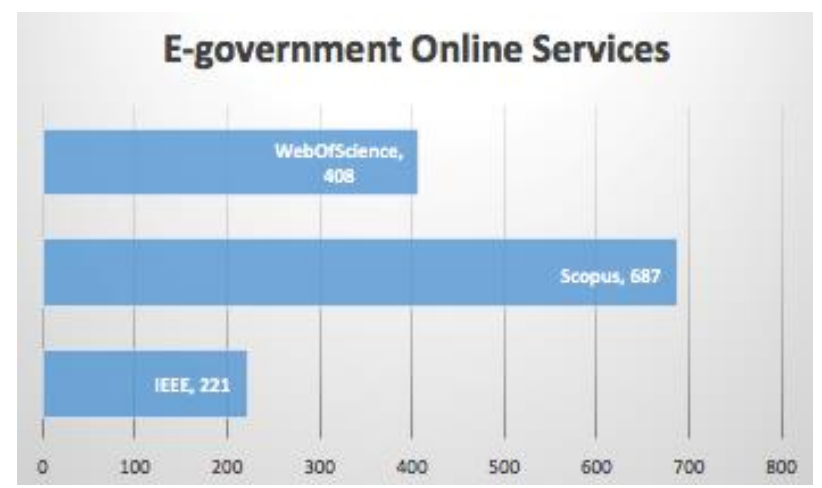

Figure 1: Databases Search Result "E-government Online Service" Keyword

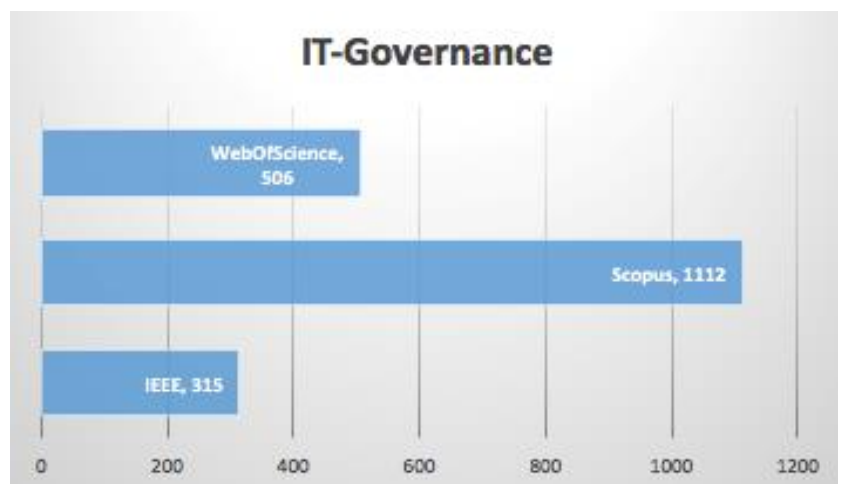

Figure 2: Databases Search Result "IT-Governance" Keyword 
Aris Suhada Mian

How ICT Implementations Impact on Managing Real Estate: At DGSAM, Ministry of Finance, Indonesia

The distribution results from three databases can be seen at Figure 1 and Figure 2 for each keyword. Scopus generates the highest number references with 687 and 1112 (journals or papers), for E-government online service and ITGovernance keywords respectively. Although IEEE only produces 221 and 315 rows but it still needs to select relevant topics. Therefore, the next steps to choose relevant topics are by title selection and abstract screening.

\section{Observation and Analysis Existing Condition}

There are three business processes in DGSAM being discussed in this journal. Three primary core systems include states asset management system, valuation system, and electronic auction which represent each business process. State asset management system and electronic auction are already adopting online selfservice system, which means external user are allowed to interact with the system through internet to lodge their application forms, while valuation system is still exclusively for internal use only. Observation methods are taken from discussion with developers, IT practitioner, and users in the recent time.

\section{FINDINGS AND DISCUSSION}

\section{The Organisation Needs a CIO on Executive Committee}

The existence of CIO in the level of Ministry of Finance seems none. From a distance, it can be considered that there are various business units available. The absence of official CIO (existing only at echelon III) in DGSAM has affected on the less-bargaining power of the IT unit role. De Haes and Van Grembergen (2009) suggest that CIO is a full member of the executive committee. It could be interpreted that CIO at DGSAM at least has full responsibility and is treated equally to Echelon II. The benefit when CIO is equal to director level is the direct reporting line to the CEO or Director General. It means that there should be a group of people who support changes. In IT unit it might be essential to hire an Echelon II who reports directly to Echelon I. 
PLANNING MALAYSIA

Journal of the Malaysia Institute of Planners (2019)

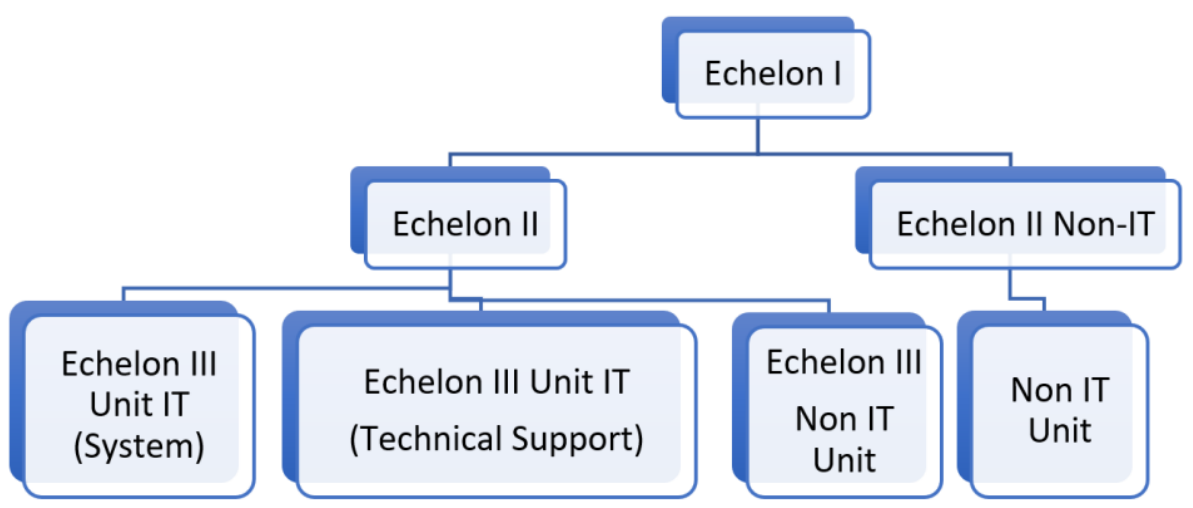

Figure 3: shows existing Structure Without Dedicated CIO

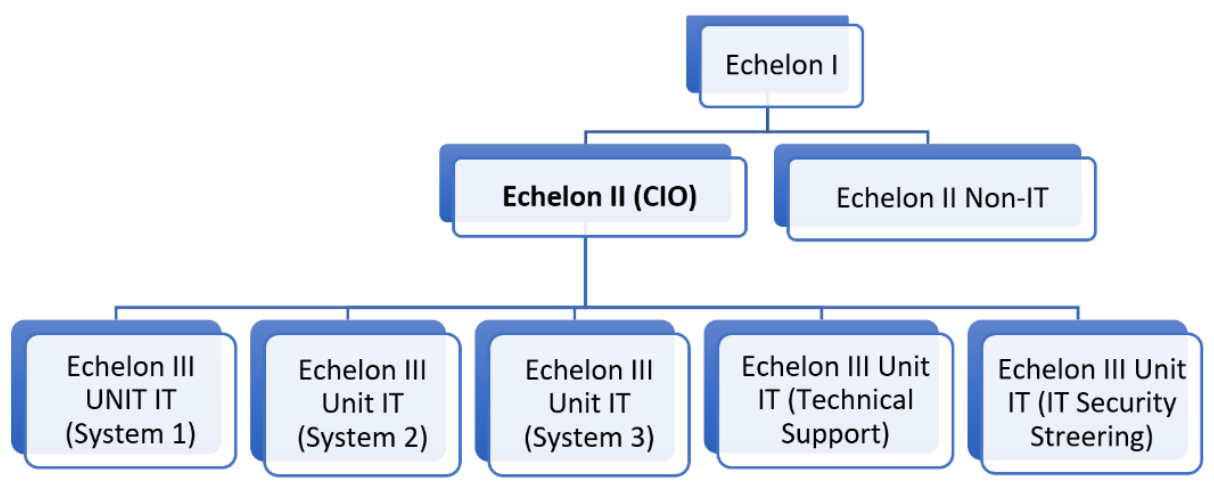

Figure 4: Proposed $\mathrm{CIO}$ as Echelon II

\section{The Organisation Needs IT Security Steering Committee}

Security and privacy issues are often mentioned in the financial business aspect related to transaction. Electronic auction service for instance, uses virtual account to transfer bond for requirement participation. Therefore, in order to define risk of information security this paper suggests DGSAM to provide a structure in the level of steering committee. This role composed of business and IT people focusing on IT related risks and security issues (De Haes \& Van Grembergen, 2009).

The implementation in DGSAM, business people determine which data are allowed to be accessed by public while IT people design security architecture from technical perspective. Take valuation system for example. Some data are restricted for internal use only, while stakeholders have to request to business unit whenever they need data i.e. valuation unit. DGSAM needs to establish security team (Figure 4) to build trust among users by creating regulation for confidentiality, integrity and availability. 
Aris Suhada Mian

How ICT Implementations Impact on Managing Real Estate: At DGSAM, Ministry of Finance, Indonesia

The Organisation Needs to Integrate Governance/Alignment Tasks in Roles \& Responsibilities

DGSAM has to prepare the readiness of organization. Preparing documentations such as operational procedures, roles and responsibilities for each level of employee are the parallel task during application development. Ignoring the alignment task in certain roles and taking responsibilities for granted, might cause an impact on the reluctance usage continuance and ticket incident. Therefore, documented roles are needed for mapping employees and their responsibilities.

\section{The Organisation Needs to Establish Service Level Agreement}

Stakeholders seem not really satisfied with the service time frame delivery. It is proven by the low index score. According to survey in document customer satisfaction 2015, time to resolve service still becomes the main concern. In fact, it has low score: 3.92 out of 5.00 (UGM, 2015). Users demand DGSAM to deliver services on time. In addition, they also request to provide status monitoring system or notification system so then users are able to see their progress.

Uncertain processing time may arise due to the lack of IT skill, IT infrastructure or digital device. A solution to solve the problem above is by optimizing the utilisation of online service. An approach such as decision making on which services possibly could be performed by online to reduce processing time is considered. To ensure that online service delivery is punctual, it is important to set SLA, the formal agreements between business and IT about IT development projects or IT operations.

\section{The Organisation Needs a Processes of Project Governance/Management Methodologies}

Project governance/management methodologies set processes and methodologies to govern and manage IT projects. This framework is addressing the issue of shortage IT skill by deciding either internal development or hiring the third party. Indeed, the process of project governance is not terminated until development is completed in the future. Project maintenance is also important part to ensure project continuance. The best practice such as Project Management Body of Knowledge (PMBoK) is recommended. The first IT Blueprint DGSAM created in 2007, and the second had been made in 2016. Those blueprints illustrate project plan for each year.

The Organisation Needs a Processes of Benefits Management and Reporting Executive or project sponsor needs to be convinced that their IT investment return is profitable and has significant value added. Therefore, it is an important process to monitor the planned business which benefits DGSAM during and after the implementation of the IT investments/projects. In this step, the IT unit has to analyse the benefit by utilising online service compared with traditional one then 
PLANNING MALAYSIA

Journal of the Malaysia Institute of Planners (2019)

reporting to the decision maker. For example; comparing on site reconciliation online by using state assets management system, comparing the potential capital gain of electronic bidding to conventional auction, or calculating the cost operational reduction if it is shifted to digital document on electronic auction.

\section{The Organisation Needs Job Rotation (IT and Business People)}

Business/IT alignment would be achieved by creating Job rotation. Job rotation defines IT staff working in the business units and business people working in IT (De Haes \& Van Grembergen, 2009). The purpose of Job-rotation is to urge employees to have better understanding of business as well as IT concurrently. The business people have to comprehend the concept of IT implementation. Similarly, IT people should know the core business including legal aspect and regulation. It is expected to make a breakthrough from understanding both sides. That breakthrough would perceive as an innovation that might increase organisation performance and could offer competitive advantages.

\section{The Organisation Needs Cross Training}

Stakeholder's acceptance of ICT implementation, i.e. e-auction, is in line with the effort of increasing participation. Training and education services along with financial supports from government would be suggested to focus on the importance of the general attitude of implementer toward technology for technology-intensive policies (Moynihan, 2004). Target level of training might vary from internal to external stakeholders. For example, seller and buyer need education in electronic auction in term of building trust, confidence and participation, whereas an administrator of electronic auction in branch office tends to resolve probability of any problems occurred. Intensive and regular training consume money and time, therefore, online training could be an effective alternative approach.

\section{The Organisation Needs IT Leadership}

There is no position in DGSAM that generates enough power for encouraging managerial level to adopt IT as a new strategic initiative. An absence of CIO in DGSAM has contributed to lack of IT leadership, the ability of CIO or similar role to articulate a vision for IT's role in the organisation and to ensure the vision is clearly understood by managers (De Haes \& Van Grembergen, 2009). In the DGSAM case, IT leadership should enable the entity to transform.

\section{CONCLUSION}

The implication of this paper for government organisation is the significant role of IT-governance to generate impact on e-government implementation. Specifically, to support online service implementation, DGSAM should reorganise structure of IT unit (existence of CIO, steering committee, and roles and responsibilities). DGSAM's processes demand to be a simplification of business 
Aris Suhada Mian

How ICT Implementations Impact on Managing Real Estate: At DGSAM, Ministry of Finance, Indonesia

process and select which business process preferred to be online by considering the efficiency and the effectiveness. The additional cost for job-rotation scheme, upgrading employee's knowledge, IT leadership campaign could occur on the allocated budget. Suggestion for future research are : collecting two sets of data, one from a user who has no experience using online system then compare his satisfaction after switching to online-base for knowing such index of current result survey for stakeholders. Those results exploit evidence of successful implementation of the online service and to prove that e-government brings benefits compare to the conventional way.

Ubiquitous internet network is the requirement for total implementation of e-government online service. In addition, all stakeholders also require computer literacy. Therefore, to ensure fairness of survey participation equality, it is essential to all stakeholders to be ready for computerisation. However, this paper only limits three components from each framework.

This report outlines an analysis of the strategy formulation that might be adopted by DGSAM in three different aspects of EGIT framework for managing the implementation of online services in e-government in Indonesia. In the beginning, this paper through systematic literature review has gathered the global characteristics of online services implementation aspects: opportunities and challenges. The aspects of technological, social and organisational perspectives are presented such as cost, security and privacy, integration, digital divide, IT skill, and organisational barriers. Furthermore, the use of IT-governance framework is considered to overcome these challenges since it could facilitate DGSAM to achieve better business/IT alignment. Business/IT alignment, strongly leads to the high performance of business values which increases public service and customer satisfaction. Therefore, the analysis of each element in ITgovernance frameworks is to obtain suitable strategy formulation in the online service context in DGSAM.

The first component framework, the structure, propose bigger IT unit than the existing one. The proposed enables to cover the need of CIO, IT security steering committee and officer, and the formulation of roles and responsibilities of business/IT to support online service implementation. The second component, the process, consists of SLA, project management, and reporting. It is also about the best practice in IT industry appliances or tools such as project management and information security management. The last, relational mechanism such as job-rotation, cross training and IT leadership should be taken into account for accomplishing ICT Implementation on managing real estate by DGSAM.

\section{REFERENCES}

Angelopoulos, S., Kitsios, F., Kofakis, P., \& Papadopoulos, T. (2010). Emerging barriers in e-government implementation. 
PLANNING MALAYSIA

Journal of the Malaysia Institute of Planners (2019)

Blanton, J. E., Watson, H. J., \& Moody, J. (1992). Toward a better understanding of information technology organization: A comparative case study. MIS quarterly, 16(4), 531-555.

Chen, Y.-C., \& Gant, J. (2002). Transforming local e-government services: the use of application service providers. Government Information Quarterly, 18(4), 343-355.

De Haes, S., \& Van Grembergen, W. (2009). An Exploratory Study into IT Governance Implementations and its Impact on Business/IT Alignment. Information Systems Management, 26(2), 123-137.

De Haes, S., \& Van Grembergen, W. (2015). Enterprise governance of information technology. Achieving Alignment and Value, Featuring COBIT, 5.

Ebrahim, Z., \& Irani, Z. (2005). E-government adoption: Architecture and barriers. Business Process Management Journal, 11(5), 589-611.

Gefen, D., Warkentin, M., Pavlou, P., \& Rose, G. (2002). Egovernment adoption. AMCIS 2002 Proceedings, 83.

Jen-Hung, H., \& Stacy Huey-Pyng, S. (2008). E-government web site enhancement opportunities: A learning perspective. The Electronic Library, 26(4), 545-560.

Kaplan, R. S., \& Norton, D. P. (2005). The Balanced Scorecard: Measures that drive performance. Harvard Business Review, 83(7), 172.

Liao, C., Chen, J. L., \& Yen, D. C. (2007). Theory of planning behavior (TPB) and customer satisfaction in the continued use of e-service: An integrated model. Computers in Human Behavior, 23(6), 2804-2822.

Melville, N., Kraemer, K., \& Gurbaxani, V. (2004). Review: Information technology and organizational performance: An integrative model of IT business value. MIS quarterly, 28(2), 283-322.

Moynihan, D. P. (2004). Building secure elections: E-Voting, security, and systems theory. Public Administration Review, 64(5), 515-528.

Nkohkwo, Q. N.-a., \& Islam, M. S. (2013). Challenges to the successful implementation of e-government initiatives in Sub-Saharan Africa: A Literature Review. Electronic Journal of E-Government, 11(2), 253-267.

Palijama, F., Sumpeno, S., \& Wibawa, A. D. (2016, 23-24 Aug. 2016). Developing modified PeGI indicators for e-Government Ranking method. Paper presented at the 2016 1st International Conference on Information Technology, Information Systems and Electrical Engineering (ICITISEE).

Pinho, J. C., de Lurdes Martins, M., \& Macedo, I. (2011). The effect of online service quality factors on internet usage. The International Journal of Quality \& Reliability Management, 28(7), 706-722.

Simon, H. A. (2013). Administrative behavior. Simon and Schuster. 
Aris Suhada Mian

How ICT Implementations Impact on Managing Real Estate: At DGSAM, Ministry of Finance, Indonesia

Sonnenschein, R., Loske, A., \& Buxmann, P. (2016, 5-8 Jan. 2016). Which security investments will pay off for suppliers? using the kano model to determine customers' willingness to pay. Paper presented at the 2016 49th Hawaii International Conference on System Sciences (HICSS).

UGM, K. K. R. I. (2015). Survei Kepuasan Pengguna Layanan Kementerian Keuangan RI Tahun 2015. Retrieved from http://www.kemenkeu.go.id/sites/default/files/Laporan\%203\%20 (Kuesioner\%20A\%20dan\%20B)\%20

UNPAN (2016). UN e-Government Survey 2016. E-Government in support of sustainable development.

Van Grembergen, W., \& De Haes, S. (2009). Enterprise governance of information technology: achieving strategic alignment and value: Springer Science \& Business Media.

Van Grembergen, W., \& Saull, R. (2001, 2001). Aligning business and information technology through the balanced scorecard at a major Canadian financial group: its status measured with an IT BSC maturity model.

Whitman, M., \& Mattord, H. (2014). Management of Information Security. USA: Cengage Learning. 